\title{
ASSESMENT OF EDUCATINAL GOALS IN TEACHING OF INFORMATICS
}

\section{Janka MAJHEROVÁ}

\begin{abstract}
In this paper we present our experiences with the creation of education targets in teaching of informatics by application of revised Bloom's taxonomy. We also want to mention a qualitative approach in the assessment of cognitive aspects of teaching with the method of grounded theory.
\end{abstract}

Key words: educational goals, revised Bloom's taxonomy, teaching of informatics, grounded theory.

\section{HODNOTENIE VZDELÁVACÍCH CIELOV VO VYUČOVANÍ INFORMATIKY}

\begin{abstract}
Abstrakt: V príspevku uvádzame skúsenosti s tvorbou vzdelávacích ciel'ov pri vyučovaní informatiky podl'a upravenej Bloomovej taxonómie. Zároveň chceme poukázat' na kvalitatívne hodnotenie produktov výučby pomocou metódy zakotvenej teórie.
\end{abstract}

Kl'účové slová: vzdelávacie ciele, upravená Bloomova taxonómia, vyučovanie informatiky, zakotvená teória.

\section{Úvod}

$\mathrm{V}$ rámci výskumu výučby témy modelovanie $\mathrm{v}$ predmete informatika na strednej škole sme realizovali experimentálnu výučbu $\mathrm{v} 1$. ročníku gymnázia. Ciel'om výskumu bolo overit' spôsob zaradenia témy modelovanie do výučby informatiky ako súčast' výučby algoritmizácie a programovania na strednej škole. Čiastkové ciele práce boli:

- preskúmat doterajšie poznatky teórie vyučovania informatiky v oblasti modelovania v predmete informatika v sekundárnom vzdelávaní,

- overit', aké formy modelov a modelovania je vhodné rozvíjat' vo vyučovaní informatiky na stredných školách ako doplnok výučby algoritmizácie a programovania,

- overit', nakol'ko použitie modelovania vo výučbe informatiky podporí zlepšenie algoritmického myslenia študentov a ich programovacích zručností.

Pri realizácii ciel'ov práce sme použili viaceré výskumné metódy. Na získanie dát sme používali participačné pozorovanie s úplnou participáciou počas výučby, neštrukturované interview so žiakmi a obsahovú analýzu produktov vzdelávacej činnosti.

Výstupom výučby boli viaceré vzdelávacie produkty žiakov - projekty a programy, ktoré predstavovali dáta nášho výskumu. $\mathrm{Na}$ ich analýzu sme použili metódu zakotvenej teórie (grounded theory). Motiváciou pre použitie tejto metódy boli výskumné práce $\mathrm{v}$ teórii vyučovania matematiky autoriek Stehlíková a Bolibruchová (2008).

\section{Tvorba vzdelávacích ciel'ov podl'a upravenej Bloomovej taxonómie}

Vzdelávacie ciele výučby sme stanovili podl'a poznatkov upravenej Bloomovej taxonómie (UBT), ktorá vznikla doplnením pôvodnej Bloomovej taxonómie pod vplyvom rozvoja kognitívnej psychológie a požiadaviek praxe (Anderson, 2001). Zameriava sa na kognitívnu doménu, vktorej je podla autorov t’ažisko výučby. Upravená (revidovaná) Bloomova taxonómia vzdelávacích ciel'ov je dvojdimenzionálna. Jednu dimenziu taxonómie tvorí znalostná dimenzia a druhú dimenzia kognitívneho procesu (tab. 1).

Znalostnú dimenziu autori vytvorili z najširšsej kategórie pôvodnej Bloomovej taxonómie vedomosti, ktorú rozčlenili na štyri kategórie: faktické poznatky, konceptuálne poznatky, procedurálne poznatky a metakognitívne poznatky.

Druhú dimenziu UBT - dimenziu kognitívneho procesu tvorí šest' kategórií: zapamätat' si, porozumiet', aplikovat', analyzovat', hodnotit', tvorit' (tab. 1). Kognitívne dimenzie sú na rozdiel od pôvodnej Bloomovej taxonómie uvádzané v tvare slovesa (verbum), kým znalostné dimenzie sú $\mathrm{v}$ tvare podstatného mena (substantívum). Súvisí to $\mathrm{s}$ formulovaním vzdelávacích ciel'ov výučby (Hudecová, 2008). 
Tab. 1: Dimenzie upravenej Bloomovej taxonómie.

\begin{tabular}{|c|c|c|c|c|c|c|c|}
\hline & \multicolumn{6}{|c|}{ DIMENZIA KOGNITÍVNEHO PROCESU } \\
\hline & & $\begin{array}{c}1 . \\
\text { Zapamätat' si }\end{array}$ & $\begin{array}{c}2 . \\
\text { Porozumiet' }\end{array}$ & $\begin{array}{c}3 . \\
\text { Aplikovat' }\end{array}$ & $\begin{array}{c}4 . \\
\text { Analyzovat' }\end{array}$ & $\begin{array}{c}5 . \\
\text { Hodnotit' }\end{array}$ & $\begin{array}{c}6 . \\
\text { Tvorit' }\end{array}$ \\
\hline \multirow{4}{*}{ 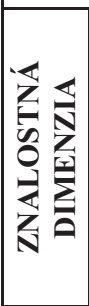 } & \begin{tabular}{|l|} 
A. faktické \\
poznatky
\end{tabular} & & & & & & \\
\hline & $\begin{array}{l}\text { B. konceptuálne } \\
\text { poznatky }\end{array}$ & & & & & & \\
\hline & $\begin{array}{l}\text { C. procedurálne } \\
\text { poznatky }\end{array}$ & & & & & & \\
\hline & $\begin{array}{l}\text { D.metakognitívne } \\
\text { poznatky }\end{array}$ & & & & & & \\
\hline
\end{tabular}

\section{Vstupná etapa výskumu}

Súčastou nášho výskumu bola etapa predvýskumu, ktorú tvorilo desat' hodín výučby tematického celku Algoritmy a vizuálne programovanie v ciel'ovej skupine. Ciel'om tejto časti výučby bolo oboznámit žiakov s prostredím

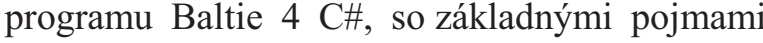
algoritmizácie a so základmi programovania pomocou grafických úloh. Overili sme použitie programovacieho prostredia Baltie $4 \mathrm{CH}$ v konkrétnej skupine žiakov a úroveň vedomostí žiakov o algoritmoch, programovaní a modelovaní.

Žiaci boli začiatočníci v programovaní. Tomuto zisteniu bol prispôsobený aj priebeh výučby.

Pre vstupnú analýzu nášho výskumu sme použili žiacke riešenia úlohy semafor. $\mathrm{V}$ tejto úlohe ide o vytvorenie jednoduchého grafického modelu (obr. 1). Účelom modelovania bolo simulovat' cyklický režim blikania oranžovej farby $\mathrm{v}$ semafore. $\mathrm{V}$ úlohe sa nevyžadovalo použitie premenných a procedúr.

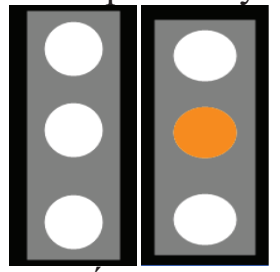

Obr. 1: Uloha semafor.

Ciel'om bolo overit' u žiakov schopnost' navrhnút' a realizovat' jednoduchý grafický model, čo znamená navrhnút' postup riešenia, zapísat' ho v programovacom prostredí, použit' správne parametre príkazov, porozumiet' a použit' jednoduchý cyklus. Od žiaka sa pri riešení tejto úlohy vyžaduje úroveň zapamätania a porozumenia faktických a konceptuálnych poznatkov, ako aj aplikácia vedomostí a zručností (procesuálne poznatky). Pre správne riešenie úlohy je však potrebná aj jednoduchá analýza problému. Názorne to môžeme znázornit' $\mathrm{v}$ taxonomickej tabul'ke podl'a upravenej Bloomovej taxonómie (tab. 2).

Tab. 2: Dimenzie vzdelávacích ciel'ov.

\begin{tabular}{|l|l|l|l|l|l|l|}
\hline & 1 & 2 & 3 & 4 & 5 & 6 \\
\hline $\mathrm{A}$ & $\mathrm{X}$ & $\mathrm{X}$ & & & & \\
\hline $\mathrm{B}$ & $\mathrm{X}$ & $\mathrm{X}$ & $\mathrm{X}$ & $\mathrm{X}$ & & \\
\hline $\mathrm{C}$ & & $\mathrm{X}$ & $\mathrm{X}$ & $\mathrm{X}$ & & \\
\hline $\mathrm{D}$ & & & & & & \\
\hline
\end{tabular}

Hodnotili sme správnost' riešenia, efektívnost' a prehl'adnost' zápisu programu. Z 12 žiakov štyria vyriešili úlohu správne, ôsmi mali program čiastočne správny. Niektoré programy neboli správne kvôli jednému nesprávnemu príkazu, ktorý nevedeli žiaci opravit' (použili nesprávne parametre pre kruh a pod.).

Je zrejmé, že z kvantitatívneho hodnotenia žiackych riešení sme získali iba čiastočný obraz o úrovni procesu ich myslenia pri riešení úlohy na počítači. Preto sme sa d'alej zamerali na kvalitatívnu analýzu dát, pričom sme použili postup podl'a metódy zakotvenej teórie.

\section{Návrh kategórií podl'a zakotvenej teórie}

Metóda zakotvenej teórie, ktorú vyvinuli autori Strauss a Glaser a modifikovali Strauss a Corbinová (Hendl, 2005, s. 243), je stratégiou kvalitatívneho výskumu a zároveň je spôsobom na analýzu získaných dát. Ciel’om zakotvenej teórie je návrh teórie na základe dát získaných pri viacerých vstupoch do terénu (Strauss, Corbinová, 1999). Medzi jednotlivými zbermi dát sa dáta analyzujú. Ústredným procesom tvorby teórie $\mathrm{z}$ dát je kódovanie. $\mathrm{V}$ zakotvenej teórii ide o tri hlavné typy kódovania - otvorené, axiálne a selektívne. Tieto typy nemusíme používat' 
úplne oddelene, môžeme medzi nimi podl'a potreby prechádzat'.

Pri otvorenom kódovaní analyzujeme získané dáta a výsledkom sú pojmy (pomenované javy), ktoré sa združujú do kategórií. Zároveň určujeme vlastnosti a dimenzie kategórí́. Po otvorenom kódovaní dáta znovu usporiadame $\mathrm{v}$ axiálnom kódovaní prostredníctvom vytvárania spojení medzi kategóriami. Vytvárame podkategórie, čiže podmienky javov, príčinné súvislosti, stratégie a následky javov. Ked' máme dobre usporiadané koncepty a kategórie, začneme s integráciou výsledkov. Pri selektívnom kódovaní vyberieme jednu centrálnu kategóriu, ktorá je vo vzt’ahu sostatnými kategóriami (Gavora, 2006, s.140).

Pri použití metódy zakotvenej teórie pri analýze získaných dát sme sa zamerali na javy, ktoré súviseli s ciel’om nášho výskumu. Otvorené kódovanie sme realizovali kódovaním kategórií spojených $\mathrm{s}$ algoritmizáciou a programovaním $\mathrm{v}$ súčinnosti s modelovaním. Pri určení názvov kategórií sme vychádzali z obsahového a výkonového štandardu témy Algoritmy pre stredné školy (ŠPÚ, 2008).

Kategórie algoritmizácie a programovania:

- žiak opíše postup, ktorý použil na riešenie problému,

- riešenie problému rozloží na postupnost' elementárnych krokov,

- rozumie zápisu algoritmu a interpretuje ho,

- overí správnost' algoritmu testovaním,

- uvažuje nad správnost'ou a efektívnostou postupu,

- používa cykly,

- používa parametre príkazov,

- analyzuje a testuje jednoduché programy,

- nachádza a opravuje jednoduché chyby v programe.

Kategórie spojené s modelovaním:

- žiak určí a analyzuje jednotlivé zložky modelu,

- navrhne postupnost' krokov pri tvorbe modelu,

- zmení vlastnosti modelu,

- ovláda realizáciu modelu v programovacím prostredí.

\section{Analýza dát}

Pre účely kvalitatívneho skúmania sme realizovali so žiakmi neštrukturované interview, v ktorých opisovali svoje riešenia. Žiakov sme sa pýtali, či vedia program opravit', ak nebol správny alebo upravit', aby sa zmenil výstup. Záznamy rozhovorov sme prepísali do textovej podoby, následne kódovali po odsekoch a vyznačili kategórie.

Pri analýze programov žiakov sme sa zamerali najmä na vytvorenie správneho algoritmu, jeho zápis v programovacom prostredí, správnost' programu, použitie cyklu a parametrov príkazov ako aj správnost' vytvoreného modelu. Ako ukážku uvedieme analýzu dát u Andrey.

Andrea mala program semafor čiastočne správny. Oranžová farba svietila trvalo. Použila cyklus, ale nepoužila správne príkazy. Komentáre použila len v prvej časti programu. Parametre príkazov nastavila správne (obr. 2). Pri interview s Andreou sme v opise postupu jej riešenia našli nasledovné kategórie: zostavila postup riešenia úlohy, navrhla postupnost' krokov pri tvorbe modelu, vyjadrila riešenie problému v špecifickom zápise, použila parametre príkazov, opravila jednoduché chyby v programe.

Andrea cyklus použila, ale nevedela analyzovat', prečo program nepracuje správne. Nevedela upravit' vlastnosti modelu. Andrea dosiahla úrovne zapamätania a čiastočného porozumenia a používania vedomostí a zručností, čo môžeme vyjadrit' $\mathrm{v}$ taxonomickej tabul'ke podl'a UBT (tab. 3).

Tab. 3: Dimenzie kategórií pre Andreu.

\begin{tabular}{|l|l|l|l|l|l|l|}
\hline & 1 & 2 & 3 & 4 & 5 & 6 \\
\hline $\mathrm{A}$ & $\mathrm{X}$ & & & & & \\
\hline $\mathrm{B}$ & $\mathrm{X}$ & $\mathrm{X}$ & & & & \\
\hline $\mathrm{C}$ & & $\mathrm{X}$ & $\mathrm{X}$ & & & \\
\hline $\mathrm{D}$ & & & & & & \\
\hline
\end{tabular}




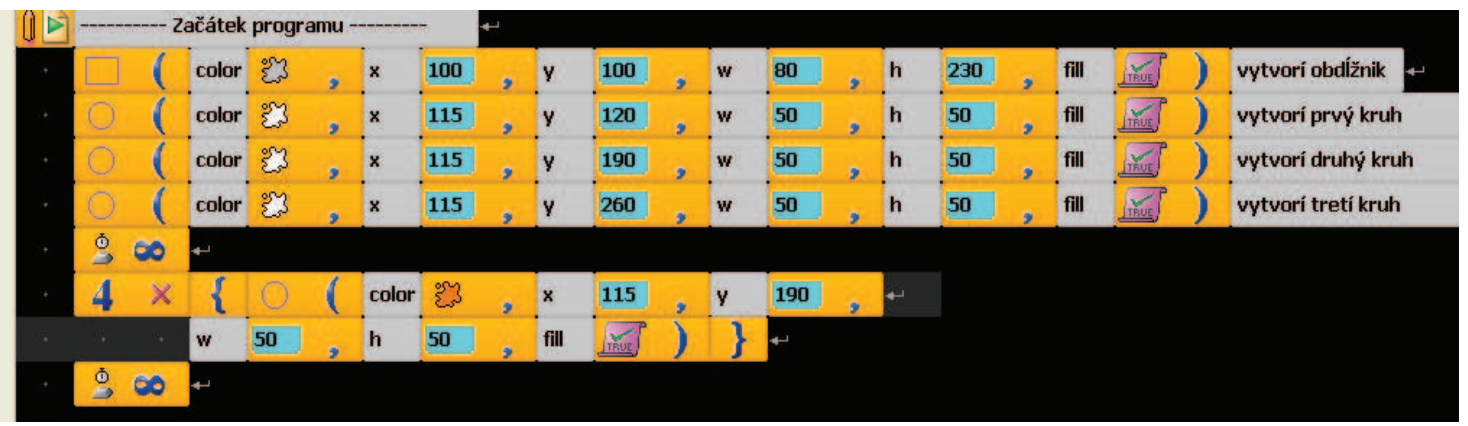

Obr. 2: Kód programu semafor Andrey.

$\mathrm{Na}$ porovnanie uvedieme ešte program a tabul'ku Lenky. Lenka získala za riešenie plný počet bodov. Jej program je prehl’adný a správny. Lenka dosiahla úrovne zapamätania, porozumenia a používania vedomostí a zručností (tab. 4). Navyše vedela analyzovat' a použit' príkaz cyklu s podmienkou v novom príklade. Ako jediná zo žiakov použila cyklus s podmienkou, ktorý mali žiaci počas prechádzajúcej výučby vysvetlený $\mathrm{v}$ inom príklade. (obr. 3).
Tab. 4: Dimenzie kategórii pre Lenku.

\begin{tabular}{|l|l|l|l|l|l|l|}
\hline & 1 & 2 & 3 & 4 & 5 & 6 \\
\hline $\mathrm{A}$ & $\mathrm{X}$ & $\mathrm{X}$ & & & & \\
\hline $\mathrm{B}$ & $\mathrm{X}$ & $\mathrm{X}$ & $\mathrm{X}$ & $\mathrm{X}$ & & \\
\hline $\mathrm{C}$ & & $\mathrm{X}$ & $\mathrm{X}$ & $\mathrm{X}$ & & \\
\hline $\mathrm{D}$ & & & & & & \\
\hline
\end{tabular}

Podobne sme podl'a prítomných kategórií $\mathrm{v}$ interview a $\mathrm{v}$ programoch pre riešenie príkladu so semaforom vytvorili tabul'ky dimenzií dosiahnutých vzdelávacích ciel'ov ostatných žiakov.

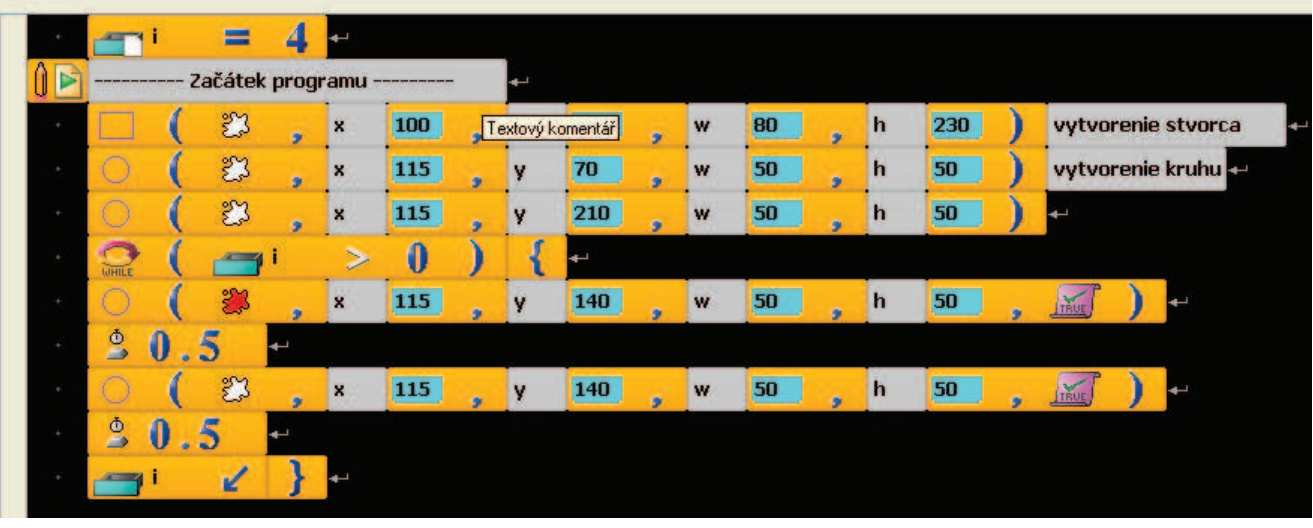

Obr. 3: Kód programu semafor Lenky.

Žiaci, ktorí nepoužili cyklus alebo ho použili nesprávne, dosiahli úroveň zapamätania a porozumenia vedomostí. U žiakov, ktorí model vytvorili správne, sme hodnotili dosiahnutie úrovne použitia a analýzy vedomostí a zručností.

Prítomnost' základných kategórií v programoch žiakov vyjadruje tabul'ka 5. Symbolom + sme označili prítomnost' kategórie, symbolom neprítomnost' kategórie. Ak žiak mal napr. algoritmus alebo program čiastočne správny, označili sme to písmenom č.

$\mathrm{Z}$ pozorovaných kategórií $\mathrm{v}$ riešení úlohy semafor vidíme, že žiaci na začiatku výskumu prejavili rôznu úroveň vedomostí a zručností pri návrhu algoritmu, programovaní a tvorbe modelu. Algoritmy pre zhotovenie modelu semafora mali väčšinou správne, postup bol pre nich jasný. Ak žiak nenaznačil v postupe riešenia opakovanie, pokladáme to za čiastočne správne riešenie. Programy boli u väčšiny žiakov správne len čiastočne, chýbala zmena farby prostredného kruhu, model bol teda čiastočne správny. Model bol u niektorých žiakov len čiastočne správny. Samostatne upravit' vlastnosti modelu, napr. zmenit' režim semafora, vedeli len dvaja žiaci. Ak pri rozhovore o riešení úlohy žiaci vedeli opravit' svoju chybu v programe alebo upravit' model, hodnotili sme to ako schopnost' analyzovat' poznatky. 
Tab. 5: Výskyt kategórií v riešeniach programu semafor.

\begin{tabular}{|c|c|c|c|c|c|}
\hline & Algoritmus & \multicolumn{2}{|c|}{ Program } & \multicolumn{2}{|c|}{ Model } \\
\hline & návrh+zápis & správnost' & Cyklus & návrh & zmena \\
\hline Lukášs & $\check{c}$ & $\check{c}$ & - & $\check{c}$ & - \\
\hline Juraj & $\check{c}$ & $\check{c}$ & - & $\check{c}$ & - \\
\hline Pavol & $\check{c}$ & $\check{c}$ & - & $\check{\mathrm{c}}$ & - \\
\hline Jana & $\check{c}$ & $\check{c}$ & - & $\check{c}$ & - \\
\hline Kristián & + & $\check{c}$ & - & + & - \\
\hline Zuzana & + & + & - & + & - \\
\hline Jakub & + & + & - & + & - \\
\hline Andrea & + & $\check{c}$ & + & + & - \\
\hline Anna & + & $\check{c}$ & + & + & - \\
\hline Zuzka & + & $\check{c}$ & + & + & - \\
\hline Štefan & + & + & + & + & + \\
\hline Lenka & + & + & + & + & + \\
\hline
\end{tabular}

\section{Výsledky výskumu}

Po etape predvýskumu sme realizovali pät' vyučovacích jednotiek s témou Modelovanie $\mathrm{v}$ informatike, kde sme sa venovali tvorbe modelu rastlín pomocou korytnačej grafiky. Po ukončení výučby sme uskutočnili takisto rozbor žiackych produktov (programov) spolu $\mathrm{s}$ neštrukturovaným interview. Podobne ako pri úlohe semafor sme výsledky analýzy žiackych produktov podl'a metódy zakotvenej teórie zhrnuli do tabul'ky kategórií (tab. 6). Sledovali sme, či žiak správne navrhol a zapísal algoritmus na vytvorenie modelu rastliny, či v programe použil cyklus, premenné a procedúru, ako navrhol model a či ho vedel zmenit'. Pri tvorbe modelu rastliny vidíme podl'a tabul'ky u väčšiny študentov prítomnost' kategórií súvisiacich $\mathrm{s}$ algoritmizáciou, programovaním a modelovaním.

Každý žiak vedel navrhnút' a zapísat' algoritmus na vytvorenie grafického modelu rastliny. Pri realizácii modelu v programovacom prostredí všetci použili cyklus. Premenné a procedúry používali niektorí žiaci len čiastočne, to znamená, že uprednostnili konkrétne hodnoty parametrov príkazov a procedúr (Jana, Jakub, Andrea). Približne polovica žiakov vedela vytvorit' vlastnú procedúru, čo charakterizuje vyššiu úroveň programovacích zručností na úrovni analýzy (Kristián, Zuzana, Štefan, Lenka).

Tab. 6: Výskyt kategórii pri tvorbe modelu rastliny

\begin{tabular}{|c|c|c|c|c|c|c|}
\hline & Algoritmus & \multicolumn{3}{|c|}{ Program } & \multicolumn{2}{|c|}{ Model } \\
\hline & návrh+zápis & cyklus & premenná & procedúra & návrh & zmena \\
\hline Lukáš & + & + & + & с̌ & + & - \\
\hline Juraj & + & + & + & + & + & - \\
\hline Pavol & + & + & + & č & + & + \\
\hline Jana & + & + & $\check{c}$ & č & + & + \\
\hline Kristián & + & + & + & + & + & + \\
\hline Zuzana & + & + & - & + & + & + \\
\hline Jakub & + & + & č & + & + & - \\
\hline Andrea & + & + & $\check{c}$ & $\check{c}$ & + & + \\
\hline Anna & + & + & č & $\check{c}$ & + & + \\
\hline Zuzka & + & + & č & $\check{c}$ & + & + \\
\hline Štefan & + & + & + & + & + & + \\
\hline Lenka & + & + & + & + & + & + \\
\hline
\end{tabular}


Pri porovnaní tabuliek 5 a 6 vidíme posun úrovne vedomostí a zručností u každého žiaka. Rozdiely medzi žiakmi sú podl’a nás spôsobené rôznou dispozíciou žiakov pre vyššiu úroveň kognitívnych operácií. Často pristupovali $\mathrm{k}$ tomu aj subjektívne príčiny, napr. vzt’ah k predmetu informatika.

\section{Záver}

Určenie vzdelávacieho ciel’a a didaktických aktivít podla poznatkov upravenej Bloomovej taxonómie prispelo $\mathrm{k}$ zefektívneniu našej výučby počas výskumu a $\mathrm{k}$ výberu vhodných aktivít na vyučovacej hodine, čo pokladáme za jeden z prínosov nášho výskumu. Podl'a tejto taxonómie sme tiež hodnotili úrovne vedomostí a zručností dosiahnuté žiakmi. Naším ciel'om bolo, aby žiak neostal len pri úrovni zapamätania a porozumenia, ale vedel použit' svoje vedomosti a analyzovat' ich pri riešení iného problému. Získava tak klúčcové kompetencie potrebné pre jeho d'alšie štúdium a odbornost' (Kútna, 2009).

Stratégia kvalitatívneho prístupu a použitie metódy zakotvenej teórie pri analýze dát výskumu sa ukázali vhodné. Pomohli nám naplnit' čiastkové ciele výskumu. Overili sme, že tvorba modelu v programovacom prostredí pomôže žiakom porozumiet' a v praxi realizovat' princípy algoritmizácie.

Modelovanie podporilo programovacie zručnosti žiakov, že si prehĺbili vedomosti a zručnosti pre prácu sprogramovacím prostredím. Tvorba grafického modelu sprostredkovala žiakom porozumenie a použitie príkaz cyklu, premenných ako aj vizuálne názorné testovanie a ladenie programu. Programy s vizuálnym výstupom modelu pomohli žiakom overit' správnost' programu a upravit' ho $\mathrm{v}$ prípade potreby.

V budúcnosti by sme chceli overit' použitie metódy zakotvenej teórie $\mathrm{v}$ celom priebehu výskumu.

\section{Literatúra:}

[1] Anderson, L. et al.: A Taxonomy for Learning, Teaching a Assessing of Educational Objectives. New York: Longman, 2001, $352 \mathrm{~s}$.

[2] Bolibruchová, M.: Rozvíjanie priestorovej predstavivosti žiakov na hodinách geometrie na 1. stupni základných škôl. Dizertačná práca. Ružomberok: PF KU 2008.
[3] Gavora, P.: Sprievodca metodológiou kvalitatívneho výskumu. Regent 2006. ISBN 80-88904-46-3

[4]Hendl, J.: Kvalitativní výzkum. Základní metody a aplikace. Praha: Portál 2005. 408 s. ISBN 80-7367-040-2

[5] Hlavatá, E. - Pecinovský, R. - Soukup, B.: Základy programování pro Baltie $4 \mathrm{C \#}$. (online). $<$ http://www.sgpsys.com/cz/metodika B4.asp/> [cit. 14. 2. 2010]

[6] Hudecová, D.: Revize Bloomovy taxonomie edukačních cílů. (on-line). $<$ http://www.msmt.cz/Files/DOC/NHRevizeB loomovytaxonomieedukace.doc $>\quad$ [cit. 10.1.2010].

[7]Kútna, A., Palásthy, H.: Didaktické aspekty IKT vo výučbe technických predmetov. In: JTIE (online). ISSN 1803-6805. Roč. 1, č. 3 (2009), s. 110-114.

[8] Majherová, J.: Modelovanie vo vyučovaní informatiky ako podpora algoritmizácie a programovania. Dizertačná práca. Bratislava: SAV 2009

[9] Rámcový vzdelávací program pre stredné školy. Obsah vzdelávania Vzdelávacia oblast' Matematické myslenie a práca s informáciami. ŠPÚ. (on-line). $<$ http://www2.statpedu.sk/buxus/docs//RVP/r vp ss 0203 matematika.pdf $>\quad$ [cit. 10.1.2010].

[10] Stehlíková, N.: Řešení multiplikativních rovnic v konečné aritmetické struktuře. In: Vagaský, M., Hejný, M. (ed.).: Pytagoras 2004 Letná škola $\mathrm{z}$ teórie vyučovania matematiky. Bratislava: EXAM, 2005, s. 8993. ISBN 80-89194-01-X.

[11] Strauss, A.- Corbinová, J.: Základy kvalitativního výzkumu. Postupy a techniky metody zakotvené teorie. Boskovice: Albert 1999. Preklad: Basics of Qualitative research: Grounded Theory Procedures and techniques. California: Newbury Park 1990. ISBN 8085834-60-X.
Autor:
Ing. Janka Majherová
Pedagogická fakulta, Katedra informatiky, Katolícka univerzita vRužomberku Hrabovská cesta 1, 03401 Ružomberok, SR e-mail: majherova@ku.sk 